\title{
Exploring the Egyptian accountants' awareness and understanding of XBRL
}

\author{
Akrum Helfaya, Ph.D. ${ }^{1}$ \\ Accounting Department, \\ Keele University, United Kingdom \\ \& \\ Damanhour University, Egypt \\ a.n.ekara.helfaya@keele.ac.uk
}

Essam Amin, Ph.D.

Accounting Department

Faculty of Commerce

Damanhour University

Egypt

Essam.amin@com.dmu.edu.eg

This is the final peer reviewed version of the following article: [Helfaya, A., \& Amin, E. (2019) Exploring the Egyptian accountants' awareness and understanding of XBRL. African Journal of Accounting, Auditing and Finance [DOI: 10.1504/AJAAF.2020.109176]. This article may be used for non-commercial purposes in accordance with African Journal of Accounting, Auditing and Finance and INDERSCIENCE PUBLISHERS terms and conditions for self-archiving.

\footnotetext{
${ }^{1}$ Corresponding author
} 


\begin{abstract}
Online reporting is now widespread with $82 \%$ of the top 100 listed companies in Egypt providing a variety of financial data online. However, much of this information reflects the paper-based versions of annual reports with little attempt to enhance the usefulness of this data for decision makers. This online reporting provides the first generation (FG) of online reporting languages such as PDF, HTML, EXCEL and WORD formats. XBRL has been developed to provide a second generation (SG) of online reporting to enhance the data handling and usability of corporate reporting. The findings of a questionnaire survey in Egypt report that academics' and bankers' awareness of XBRL and SG reporting is very little compared to FG reporting formats. Additionally, the vast majority of respondents are aware of both the benefits and problems of adopting XBRL. This study has some recommendations for Egyptian regulators, standards' setters, accounting academics and professional accountants.
\end{abstract}

Keywords: Corporate reporting; Digital reporting; XBRL; Stakeholder engagement; Egypt. 


\section{Introduction}

Due to advances in technology and the search for new ways to improve business reporting, the way in which corporate reporting has been developed in recent years enhances the way information is retrieved, stored and managed (Pinsker and Wheeler, 2009; Steenkamp and Nel, 2012). The first level of corporate reporting was traditional paper-based reporting, which became less useful for decision making as it is less timely, not very usable, and difficult to be reused electronically (Dunne et al., 2013). Vasarhelyi et al. (2012) criticized traditional reporting by providing evidence that overwhelming data volume may force a user to make decisions based on incomplete information (see also, Chen et al., 2015). As a result, the second level of corporate reporting emerged with the use of technology to vary from the Hyper Text Markup Language (HTML), Portable Document Format (PDF), online Excel and Word documents, the first generation (FG) of online reporting, and finally, the most promising financial reporting language: eXtensible Mark-up Language (XML) and eXtensible Business Reporting Language (XBRL) (Chen et al., 2015; Srivastava and Kogan, 2010).

According to Dunne et al. (2013), XBRL is considered as the second generation (SG) of online reporting, making it easier for a stakeholder to obtain information and analyze it accurately, in a timely manner, with the XBRL-enabled software. Accordingly, XBRL has been adopted in several countries worldwide, such as the US (Debreceny et al., 2010), UK (Boritz and No, 2009; Dunne et al., 2013), Australia (Debreceny and Farewell, 2010), China (Henderson et al., 2012), South Africa (Steenkamp and Nel, 2012) and other countries. Despite this, much of the literature has found a lack of awareness about XBRL in different countries. For example, a US survey found that only $33 \%$ of the American Institute of Certified Public Accountants (AICPA) and US XBRL members have a background in XBRL (Steenkamp and Nel, 2012). In the UK, Dunne et al. (2013) found that different stakeholders had a lack of awareness about XBRL, similarly, South Africa has a very low awareness about XBRL (Nel and Steenkamp, 2008). This will hinder XBRL adoption and perceived usefulness (Bovee et al., 2002; Henderson et al., 2012).

With increasing attention being dedicated to finanancial reporting in general and to online reporting in particular as well as the development of the SG of the online reporting, XBRL, it is timely to explore the views of the Egyptian accountants of the SG digital reporting. It is clearly central to identify the main issues of this innovative langauge of corporate reporting for both reporters and users. In particular, detailed knowledage is required regarding the level of awareness and understanding of XBRL among key stakeholders, academics and professional bankers to deternmine the most effective stratgeies to support proper developments in adopting XBRL. This study, therefore, aims to addressing this omission in the Egyptian context. Egypt was selected, firstly, because as a developing country it has to increase foreign investment by attracting more international investors (Aly et al., 2010). As a result, it must look for other advanced digital financial reporting languages, such as XBRL, to offer different stakeholders accurate and fast access to corporate information. Secondly, the accounting information published by the Egyptian companies needs more complementary information sources to make the information more valuable and useful for decision making (Ahmed et al., 2017). Lastly, the lack of knowledage and interest in adopting the SG of online 
reporting in the emerging economies (Ahmed et al., 2017), and the absence of the obligatory adoption of XBRL in the stock exchanges' listing rules in most developing nations, including Egypt (e.g. Ahmed et al., 2017; Eni, 2015; Ilias et al., 2015). Thus, this study is purposefully explorative in nature and tests the Egyptian awareness and understanding of XBRL. By doing so, this study contributes to the literature on corporate financial reporting in the emerging economies and extends that literature by exploring the accountants' awaraness and perceptions of XBRL. Also, the results of this exploratory study may be useful for Egyptian Financial Supervisory Authority and standards' setters as they continue to enhance the usefullness of disclosed financial statements (Dunne et al., 2013).

The paper is structured as follows. The following section presents an overview of the existing literature on corporate reporting, XBRL, and the Egyptian reporting environment. The research methodology section describes the research method and sample. The results section provides the results of questionnaire, with discussion and conclusion following in the last section.

\section{Literature review}

\subsection{Corporate reporting}

Companies use different types of financial reporting languages to publish their financial information to different stakeholders, from the traditional paper documents to PDF, HTML, Excel and Word documents (Chen et al., 2015; Papa and Luisi, 2014). However, with the advances in the information technology and need for fast information, companies need to disclose on the web using a new interactive format such as XML and XBRL to improve information location and retrieval for better market efficiency and timely information (Ahmed et al., 2017; Debreceny et al., 2011; Eni, 2015; Valentinetti and Rea, 2012). Based on prior literature, we can categorize the corporate reporting into two types, as shown in Fig. 1 (e.g. Cohen et al., 2005; Dunne et al., 2013; Valentinetti and Rea, 2012; Beattie and Pratt, 2003). The first type is the traditional paper, which includes the paper documents, offline Excel and Word financial reports that are not available over the internet. The second is the internet financial reporting, which includes two generations: FG is the HTML, PDF and online Excel documents, and the SG is the XML and XBRL reporting (see Dunne et al., 2013).

\section{$<$ INSERT FIGURE 1>}

Corporate reporting is of great importance. For example, companies use financial reporting to justify their actions to stakeholders, reduce information asymmetry and disseminate financial information to tell outsiders about the qualities of their firms (Bovee et al., 2002). It allows for better communication between corporations and stakeholders, and facilitates the direct transmission of information in different forms (Bovee et al., 2002; Debreceny et al., 2010). Additionally, the quality features of financial information as identified in the Financial Accounting Concept Statement (SFAC) No. 2 (FASB, 1980) are consistency, comparability, reliability, relevance and decision usefulness. Baldwin and Trinkle (2011) found that XBRL could improve these characteristics for different users of electronic media (see also, Dunne et 
al., 2013). Cohen et al. (2005) and Henderson et al. (2012) argued that XBRL will increase the quality of disclosed information by enhancing its timeliness and accuracy. Similarly, Vasarhelyi et al. (2012) and Ilias et al. (2015) declared that XBRL will increase both the comparability and consistency of accounting information over different periods and industries. Recently, the Certified Financial Accountants (CFA, 2016) survey found that XBRL tagged data will increase the reliability, consistency, and comparability for analyzing company's financial position and enhance the timeliness of the valuation process. Finally, Birt et al. (2017) found that XBRL will increase the understandability and confidence level of the information disclosed to different stakeholders.

\subsection{Digital reporting and $X B R L$}

Digital reporting has been developed over many years on two levels; the "first level", FG digital reporting, which includes the HTML, Excel and PDF files (Chen et al., 2015). This means that the companies use a PDF file, or HTML or Excel to display an online version of traditional paper financial statements on the internet (Dunne et al., 2013; Papa and Luisi, 2014). Despite this, there are some problems facing both the FG reporting and the traditional reporting. For example, different interfaces of the search engine lead to difficulty of finding information and their lack of electronic usability (Dunne et al., 2013). Also, these formats cannot be indexed by a search engine or any other intelligent agents that hinder the speed of accessing this information in the financial reports (Janvrin et al., 2013; Troshani and Lymer, 2010).

Consequently, the SG of digital reporting took place to allow a more automated and effective analysis and understanding of information in corporate reports across multiple platforms including XML and XBRL, to overcome the previously stated drawbacks of the FG of digital reporting (Dunne et al., 2013). On the one hand, XML is considered as a mark-up language for the next generation of HTML which allows the information to include numbers and words with attached meaning and context (Beattie and Pratt, 2003; Eierle et al., 2014; Fedorowicz, 2011). On the other hand, XBRL is based on XML language, however it was designed specifically for business reporting to exchange financial information both within organizations, and with other organizations on different platforms (Alles and Debreceny, 2012; Bonson et al., 2009; Papa and Luisi, 2014).

XBRL was developed in April 1998 by a Certified Public Accountant named Charles Hoffman, by using XML technical standard in accounting to prepare financial reports in the US (Cohen et al., 2005). Later, Wayne Harding, chair of the American Institute of Certified Public Accountants (AICPA), worked with Hoffman to develop the XML-tagged financial reports. Earlier in 1999, AICPA became involved with other stakeholders (e.g. Microsoft, the 'Big 5' professional service firms and others) to create the XFRML project (XML-based Financial Reporting Markup Language), known as XBRL. In 2009, XBRL was adopted by the Securities and Exchange Commission (SEC), requiring corporate filers to prepare and disclose their reports in XBRL as a multi-year program in EDGAR disclosure instead of HTML and plain text disclosures, in order to change the relationship between preparers and users of financial reports (Debreceny et al., 2010; Debreceny and Farewell, 2010; Vasarhelyi et al., 2012). In the same context, the UK announced that it planned to make XBRL mandatory for company tax filings in 2010 (Boritz and No, 2009; Kim et al., 2012). 
As demonstrated in Fig. 2, XBRL consists of three main components: a) the XBRL taxonomy, which is a set of different elements used in business reporting for tagging the data such as item definition, calculation, and summarization which can be considered as the input for the XBRL tagging process; $b$ ) the tagging process, which includes an item that refers to the company that issues the information using XBRL, and c) the instance document, which is the output of the taxonomy after adding the business facts tagged in XBRL to the taxonomy (Bonson et al., 2009; Cohen et al., 2005; Valentinetti and Rea, 2012; Fedorowicz, 2011). Taxonomies can be reported under single generally accepted accounting principles (GAAP) worldwide or IFRS taxonomy and can be defined as the XBRL representation of GAAP or IFRS accounting standards in a taxonomy file to be used to enter financial facts of the company. The tagged taxonomy with the representation of corporate data and financial facts results in the instance document, where it is more readable and easy to reuse by any application (Debreceny and Farewell, 2010; Eni, 2015; Valentinetti and Rea, 2012).

\section{$<$ INSERT FIGURE 2>}

\subsection{Benefits and problems of adopting XBRL}

Prior literature stated the potential benefits of XBRL by differentiating XBRL from other reporting languages (e.g. HTML and PDF). For example, HTML reporting language describes how the information font type, size and colour appear on the web with no real context or meaning for the data presented (Dunne et al., 2013; Beattie and Pratt, 2003; Fedorowicz, 2011). While PDF files help in controlling the display of the information on a various platform using software application, XBRL is prepared for computer consumption and not designed for human readability (Cohen et al., 2005; Dunne et al., 2013). Similarly, Janvrin et al. (2013) found that users prefer XBRL over Excel, HTML and PDF formats due to its usefulness and convenience over other reporting formats. Furthermore, XBRL allows a decrease in the assembly and reentry of data processing, which allows stakeholders to focus on analysing data rather than collecting it (Apostolou and Nanopoulos, 2009; Kim et al., 2012; Pinsker and Li, 2008).

XBRL enhances the financial reporting cycle in an efficient and effective way. For example, Henderson et al. (2012) point out that the organization can process the traditional manual transactions automatically and improve the communication between an organization and its auditors in a timely manner, which in turn lowers auditing fees, improves both continuous auditing and the performance of internal control (Eierle et al., 2014; Ilias et al., 2015; Fedorowicz, 2011). Likewise, XBRL prepares integrate the financial data between different platforms and software application from different organizations with the least amount of effort (Kim et al., 2012; Pinsker and Li, 2008; Troshani and Lymer, 2010). This can be done by creating vocabulary of common financial data in the organization to facilitate data transfer through various systems (Henderson et al., 2012), which increases the added value of business information for different users' needs (Dunne et al. 2013; SEC 2005). Furthermore, it improves corporate governance, credit agency ratings and reduces their cost of capital by increasing information transparency (Ilias et al., 2015; Birt et al., 2017). Using XBRL can also enhance the financial report usability by keeping the same accounting standards through its extensibility 
(Troshani and Lymer, 2010). Furthermore, investors and financial analysts will be able to perform faster analysis by retrieving data directly from corporate financial reports, providing useful, comparable and timely information (Baldwin and Trinkle, 2011; Henderson et al., 2012; Birt et al., 2017). Using tagged data, lenders, financial analysts and other stakeholders can combine different financial reports in a simultaneous presentation to increases the efficiency of analysing and reveals the lack of similarity between companies (Kim et al., 2012).

However, many academic researches cited the problems related to XBRL adoption. For example, Dunne et al. (2013) assert that the major obstacles in applying XBRL are the time and effort required to learn it, and the knowhow needed to apply it. Additionally, Eierle et al. (2014) claim that there are certain factors affecting the application of XBRL such as: the cost of integrating XBRL with the company reporting system reflects a high level of investment; the existing reporting system, firm size and the way of integrating XBRL whether for the internal or external reporting system or both. Troshani and Lymer (2010) mentioned the need for different softwares to support the application of XBRL, and that the level of technical knowledge may hinder the usability and spread of XBRL. Finally, yet importantly, the level of understanding XBRL and its technical details consider the main problem to get the most benefit of its adoption (see Rawashdeh and Selamat, 2013).

\subsection{Awareness and perceptions of XBRL}

The widespread use of XBRL and the perceived usefulness of its benefits depends on two things. The first is the different stakeholders' awareness and perception concerning the usefulness and efficiency of XBRL (Bovee et al., 2002; Henderson et al., 2012; Rawashdeh and Selamat, 2013). The second is the lack of user awareness about the abilities and advantages of XBRL (Henderson et al., 2012). Pinsker and Wheeler (2009) found that a lack of perception on XBRL abilities will negatively affect its adoption within a different organization and increase implementation costs. So, many studies surveyed the perception of different stakeholders concerning XBRL. For example, in the US, Pinsker (2003) examined the perceptions of different accountants and auditors and found that $33 \%$ of the sample has a background of XBRL fillings. In 2016, the Certified Financial Analyst (CFA) Institute survey found a slight increase in the awareness of XBRL to be $45 \%$ compared to $41 \%$ in 2007 survey (CFA, 2016). Additionally, the majority of the participants are still not aware of XBRL including Academics, Credit Analysts, Financial Advisors, Portfolio Managers, Bankers and Research Analysts (CFA, 2016).

Dunne et al. (2013) surveyed the level of awareness in UK stakeholders including accountants, tax practitioners, auditors and different users of financial reports and found a low level of awareness concerning the SG of reporting in general, and XBRL in particular. Additionally, they reported that only $45 \%$ of investment professionals worldwide were aware of XBRL, and $1 \%$ of companies in the UK had adopted XBRL for financial reporting. In South Africa, Steenkamp and Nel (2012) found that 49\% of South African Charted Accountants did not actually know what XBRL was, $45 \%$ had a slight idea, and just $6 \%$ had some knowledge about it. In Italy, despite the obligatory adoption of XBRL for non-listed companies from 2009, there is a low level of awareness among different stakeholders. For instance, Avallone et al. (2016) found a low level of awareness of XBRL among Italian Chartered Accountants, Auditors, and 
Bankers. Such low level of awareness is due to the limited use of XBRL by reporters and/or most practitioners are tagging the financial statements to XBRL. In the Malaysian context, Ilias et al. (2015) surveyed the knowledge level of XBRL from the Malaysian Auditors, Regulators and other users of financial reports, and found that only $3 \%$ of the respondents have awareness of XBRL.

\subsection{Egyptian reporting environment}

The Egyptian Stock Exchange (EGX) considers one of the eldest and leading markets in the Middle East and North Africa region (Ahmed et al., 2017). Also, the formulation of the Egyptian Accounting Standards (EAS) which is developed taking into account the International Accounting Standards (IASs) that existed in 2005 (IFRS, 2013) where all registered Egyptian companies are obligated to apply EAS. Due to the 2011 revolution, the EGX market lost 194 billion L.E. of its value (Ahmed et al., 2017). Accordingly, in March 2011, the Egyptian Institute of Directors (EIoD) issued the revised version of the Egyptian Code of Governance and its guidelines to improve the quality of information issued by the registered companies, increase competition and attract foreign investment. For example, Section 5 guideline number 5.6.3, also by the Decision No. 15 in 2012 by the Egyptian Financial Supervisory Authority (EFSA) stated that the listed companies should have their own website on the internet, preferably in both Arabic and English languages, including financial and non-financial disclosure (EIoD, 2011; EFSA 2014). Although, these mandatory guidelines did not mention the language of the online financial reporting whether HTML, PDF, Word or XBRL (EAS 2006; EFSA 2014; EGX 2014).

In practice, during August 2016, the current study surveyed the top 100 Egyptian Listed Companies (EGX-100) by accessing their websites to investigate: 1) whether the companies' sites are available or not, and 2) what the format of financial reports provided is (e.g. PDF, HTML, XBRL, etc.). Table 1 indicates that $70 \%$ of the financial reports were PDF formats, six companies used HTML format; only one company used both HTML and PDF formats. Additionally, five companies used Hypertext Pre-processor (PHP), which is a free open source scripting language used to design interactive webpages to disclose financial reports online. Only one company used HTML and Excel reporting format. For the rest of the EGX-100 sample, we found that 14 companies have a website but do not disclose financial reports on them. Four companies do not have a website. Therefore, the EGX-100 did not use XBRL for preparing and presenting their financial reports. This result is consistent with the absence of the obligatory adoption of XBRL in the EGX listing rules (see Ahmed et al., 2017).

\section{$<$ INSERT TABLE 1>}

\subsection{Research questions}

It is noted from the discussion above that XBRL is mainly focused on a number of key stakeholder groups (e.g. reporters, investors, financial analysts, fund managers, regulators, auditors, tax practitioners, academics and other users) (e.g. Dunne et al., 2013; Debreceny and Farewell, 2010; Steenkamp and Nel, 2012; CFA, 2016; Papa and Luisi, 2014). These 
stakeholder groups are therefore the key actors who need to participate in this reporting technology for effective adoption to occur for reporters. The digital reporting system involves a number of functions other than the traditional accounting process, such as information technology, internal auditing, management reports, company and data process units (Dunne et al., 2013). In practice, these groups have different perceptions on XBRL. Additionally, the Egyptian Capital Market Law does not require listed companies to adopt XBRL. This study aims to explore the level of awareness and understanding of XBRL among Egyptian accounting academics teaching faculty students who will use and develop XBRL (Fedorowicz, 2011), and professional bankers as a representative sample of corporate stakeholders in this exploratory study. Specifically, three research questions are addressed:

\section{RQ1: How aware are the Egyptian academics and bankers of different reporting languages?}

\section{RQ2: How the Egyptian academics and bankers view the pros of using XBRL?}

\section{RQ3: How do the Egyptian academics and bankers view the cons of using XBRL?}

\section{Research methodology}

\subsection{Research method}

A literature review on academic and professional research on the different languages of corporate reporting, stakeholders' awareness and understanding of XBRL, and potential benefits and problems of adopting XBRL, was conducted. On the basis of this literature (e.g. Dunne, et al., 2013; Janvrin et al., 2013; Steenkamp and Nel, 2012; Ilias et al., 2015), a questionnaire was developed and distributed to the two stakeholder groups covering the three research questions. The questionnaire was piloted and reviewed by five accounting professors at Alexandria University, Egypt. After this step, changes were made to refine the questions asked and the manner in which these questions were presented.

The questionnaire consisted of five sections, with a brief introduction to XBRL and the steps of its application. Section 1 dealt with the respondents' demographic traits. Section 2 covered the respondents' awareness of different reporting languages. Section 3 presented two groups of balance sheets of six Egyptian banks; one prepared in accordance with the traditional reporting system and the other prepared using XBRL with FUJITSU Software Interstage XW, as this is not applicable in Egypt yet. In this section, respondents were asked questions to distinguish the difference of both reporting languages. Finally, Section 4 and 5 covered the respondents' views of both the pros and cons of XBRL respectively.

\subsection{Research sample}

The questionnaire was distributed to 340 accounting staff at both Alexandria and Damanhour universities, and 93 professional bankers in three banks in the Alexandria Governorate. The second author distributed and collected the completed responses. In total, 106 questionnaires were obtained from respondents, 57 from accounting academics (17\%) and 49 from professional bankers (53\%), providing a successful response rate of $24 \%$. Compared with the poor response rate in other business-related questionnaires (Dunne et al., 2013; Nel and 
Steenkamp, 2008; Pinsker, 2003; CFA, 2016; Eni, 2015; Beattie and Pratt, 2003; Papa and Luisi, 2014), this is considered a good response rate from a limited sample. To establish questionnaire reliability, the Cronbach's Alpha test was used (Field, 2013). The results showed that there is a reasonable degree of reliability for the information obtained from the questionnaire; the overall reliability scale is > 73).

\section{Research results}

\subsection{Respondents' demographic traits}

As Table 2 shows, the total usable responses totalled 106, comprising 57 academics (54\%), and 49 bankers (46\%). From Table 2 it is evident that $91 \%$ of respondents were less than 37 years old, while $72 \%$ were male. When respondents were asked to indicate their educational qualifications, a greater proportion of academics had MScs and/or PhDs (53\%), while a greater proportion of bankers were professionally qualified (41\%). For job experience, more than $86 \%$ of the academics reported that they had between 1 and 10 years', compared with $80 \%$ of bankers. Chi-squared and Z-tests were undertaken in order to determine whether the personal characteristics of academics and bankers were statistically different. Interestingly, age, gender and job experience showed no significant different between the two groups. However, the evidence for academics having a higher level of academic achievement was significant at the $5 \%$ level; therefore, the bankers were more likely to be professionally qualified.

\section{$<$ INSERT TABLE 2>}

\subsection{Respondents' awareness of the financial reporting languages}

The first research question investigated the extent to which both accounting academics and professional bankers were aware of the different financial reporting languages. From the questionnaire findings, Table 3 presents the respondents' awareness of the different financial reporting languages. The results related to the respondents' awareness of different formats of financial reporting in the digital environment show that all mean statistics among academics and bankers are ranged between 3.60 and 3.87 across the three formats; Excel, PDF and HTML and standard deviations averaged around 1.12, suggesting a large harmony between the two groups. It appears that more than $60 \%$ of both groups are clearly aware of both Excel and PDF formats, compared with the $53 \%$ of academics and $58 \%$ of bankers who are aware of the HTML format. It is evident that professional bankers are more aware of Excel and PDF (69\% and 76\% respectively), compared with academics (65\% and 60\% respectively). For XBRL, the result indicates that more than two-thirds of the respondents are not aware of XBRL, with an average of 2.06. As shown in Table 3, no significant differences were detected between both academics and bankers for the four formats of financial reporting languages, as measured by the KruskalWallis test.

$<$ INSERT TABLE 3> 


\subsection{Respondents' answers to some financial tasks}

To examine the two groups' views of the benefits and problems of XBRL, the respondents were firstly given two groups of balance sheets for six Egyptian Banks (A, B, C, D, E and F); the first group (A, B \& C banks), was prepared by traditional reporting language, while the second group (D, E \& F banks) in XBRL format. The first group of balance sheets for the A, $\mathrm{B} \& \mathrm{C}$ banks were printed individually, in Arabic, and using EGP pound. The second group of the balance sheets for the D, E \& F banks were printed on the same paper, in Arabic and English, with both currencies (EGP pound and US dollar), using the features of the XBRL format in order to facilitate the searching and comparing process to provide the users with a general idea of the practical benefits of XBRL. As seen in tables 4 and 5, the respondents were asked some questions based on the information available on the two groups of balance sheets to contextualize their responses about the SG of corporate reporting, XBRL and its benefits and problems (tables 6 and 7).

For the traditional balance sheets, the respondents were asked three questions (tasks) to extract and calculate some financial information from the balance sheets with gradual increases in the work needed to provide the right answer, followed by three questions concerning their agreement/disagreement about the easiness of these tasks. As shown in Table 4, there is a general consensus between the two groups for the three tasks where the correct answers for questions 5, 7 and 9 have the highest degree in both groups, as follows: $78 \%, 58 \%$ and $68 \%$ respectively. As predicted, there is an overall decrease in the respondents' agreement about the easiness of the task for questions 6,8 and 10, as follows: $58 \%, 37 \%$ and $27 \%$. Contrarily, there is a gradual increase in the respondents' disagreement about the easiness of the task; $28 \%, 38 \%$, and $45 \%$ respectively, meaning the task became harder.

For the XBRL balance sheets, as shown in Table 5, there is an overall consistency between the two groups for the three tasks where the correct answers of questions 11, 13 and 15 have the highest degree in both groups, as follows: $78 \%, 79 \%$ and $91 \%$ respectively. As predicted, there is overall a tremendous increase in the respondents' agreement about the easiness of the task for questions 12, 14 and 16, as follows: $89 \%, 90 \%$ and $92 \%$, while the disagreement of the respondents about the task easiness has the lowest ratios, as follows: $4 \%, 3 \%$ and $5 \%$ respectively.

An overall comparison between the two groups reveals that the correct answers increased for the XBRL balance sheet tasks (i.e. questions $11,13 \& 15$ ) more than the traditional balance sheets tasks (i.e. questions 5, $7 \& 9$ ), with approximately $0 \%, 21 \%$ and $23 \%$ for both groups, noting that the $0 \%$ for questions 5 and 11 reflects the easiness of both questions. Regarding the agreement and disagreement questions, there is a significant increase in the respondents' agreement in the easiness of the task by approximately $36 \%, 53 \%$ and $65 \%$ for both questions agreements groups' questions. There was a dramatic decrease in the response to the disagreement of the task easiness by approximately $24 \%, 35 \%$ and $18 \%$ respectively. As a result, we can conclude that the XBRL format can significantly facilitate the financial tasks with more accurate and efficient answers 
$<$ INSERT TABLE 4>

$<$ INSERT TABLE 5>

\subsection{Respondents' views of the pros and cons of using XBRL}

The second research question examined both academics' and bankers' views of the pros of adopting XBRL. While the vast majority of respondents reported little knowledge of XBRL, it could not unconsciously be deduced that would not know about its benefits and/or obstacles (e.g. Dunne et al., 2013). With regard to the benefits of XBRL, respondents were asked 13 questions on specific benefits suggested in the literature. The vast majority of respondents (78\% or more) claimed that they knew enough about the advantages of XBRL to answer the relevant questions. For example, Table 6 shows a significant acknowledgement that XBRL sped up "the reporting cycle and decision making process", "reduced re-entering data errors", "was interoperable", "eliminated the effort of re-key information", etc. Although the two groups were very positive, the bankers respondents were more knowledgeable with the practical matters of XBRL such as how it can "reduce efforts of re-keying", "solve the problems of different reporting languages", "solve the problems of different currencies" and "speed up the process of finding information". From Table 6, it is evident that all mean statistics of the total respondents are ranged between 4.17 and 4.60 across the 13 benefits, and standard deviations averaged around 0.82, suggesting a general consensus between both groups on the benefits of XBRL. Additionally, the Kruskal-Wallis test suggested that there are no significant differences between the two groups.

The third research question examined the cons of XBRL; the questionnaire therefore asked about the problems of its adoption. The list of potential problems for take-up of the technology was based on a review of prior relevant literature, as shown in Table 7. All means are greater than 3 and less than 4 . These results reflect that all respondents knew a little about the problems of adopting XBRL (Dunne, et al., 2013). However, those who did respond reported that across the two groups a number of key problems impeded the adoption of XBRL in corporate financial reporting. The bankers agreed more strongly than academics that "difficulty to create XBRL Egyptian official taxonomy" was a problem, although this may have reflected their greater knowledge of the Egyptian context for adopting XBRL. Approximately two-thirds of academics and bankers also thought that the "low level of users' awareness about XBRL" and "lack of training courses for developing required skills to apply XBRL" issues hindered the implementation of XBRL. In contrast, less than $40 \%$ of the two groups agreed that the "difficulty to create extension taxonomy for each company" issue could delay the adoption of XBRL. The Kruskal-Wallis test shows that there are no significant differences between the two groups on any of these problems.

$<$ INSERT TABLE 6>

$<$ INSERT TABLE 7> 


\section{Discussion and conclusion}

XBRL is an important technology for the electronic reporting of business information and its relevance to different stakeholders. After reviewing the XBRL literature in different countries, in which low levels of awareness and understanding of XBRL and its benefits and risks were reported (e.g. Dunne et al., 2013; Janvrin et al., 2013; CFA, 2016; Eni, 2015; Avallone et al., 2016), this study explored the Egyptian accounting academics' and bankers' awareness and understanding of XBRL. A questionnaire was developed and distributed to accounting staff at two Egyptian Universities and three commercial banks at Alexandria governorate, Egypt.

Our findings revealed that the majority of respondents were aware of the three reporting languages, namely, Excel, PDF and HTML which are consistent with Ilias et al's findings (2015). These results also demonstrated a significant lack of knowledge about XBRL among the majority of both academics and professional bankers. Again these results support the findings of the EGX-100 companies survey as seen in Table 1 and prior XBRL literature (e.g. Avallone et al., 2016; Eni, 2015). The PDF reporting was the highest language used. This is perhaps not surprising given that using XBRL is not required in Egypt. For the potential benefits of adopting XBRL, it was found that there is a general consensus between the two groups about the benefits of XBRL and its major impact on their companies' reporting system. Most respondents had a sound understanding of using XBRL to enhance the searching, comparing and analysing a different set of financial reports to assess performance and make investment decisions (e.g. CFA, 2016; Eni, 2015; Papa and Luisi, 2014; Birt et al., 2017). Similarly, the problems related to adopting XBRL were perceived to be high. For example, cost and difficulty, user awareness, technical matters, absence of Egyptian-regulated standards and taxonomy, and training costs, were perceived to be the barriers to using XBRL (see Dunne et al., 2013; Eni, 2015; Rawashdeh and Selamat, 2013).

From the results of this study, the following policy and societal implications arise. According to Dunne et al. (2013), electronic information is viewed by its potential users as being comprehensive, material and truthful, and those users can be assured about the credibility of XBRL information. For full adoption of XBRL to occur, the Egyptian accounting regulators need to mandate XBRL for listed companies to improve efficiencies in data handling for reporters and usability of published information for readers. Additionally, Egyptian professional bodies (e.g. the Egyptian Institute of Directors, the Egyptian Stock Exchange; the Egyptian Financial Supervisory Authority, the Accountability State Authority, and the Egyptian Society of Accountants and Auditors) need to raise the profile of XBRL. Other professional practitioners, such as auditors, tax accountants and IT experts, should be involved in XBRL government-led initiatives to make recommendations to their clients (see, Eni, 2015; Ilias et al., 2015). Similarly, accounting academics could play an important role in the diffusion of XBRL by impeding XBRL into the accounting curriculum and introducing new accounting modules, such as Computerized Accounting, Cloud Accounting, and Computer-assisted Reporting (e.g. Fedorowicz, 2011). XBRL also has numerous and diverse societal impacts. For example, XBRL enables the unified integration of disparate technologies, platforms and software applications of preparing the financial statements within companies and among stakeholders. This will lead to significant reductions in the processing of financial information 
for all stakeholders and then enhance the efficiency of the capital markets. Overall, the benefits of XBRL need to be viewed far more transparent so that the XBRL business case becomes well known for the large business society (see, Dunne et al., 2013).

Some limitations are acknowledged in this exploratory study, such as the small sample of the relevant XBRL community, accounting academics and professional bankers, and the low response rate and findings discussed here should be interpreted with this in mind. Additionally, the respondents represent only two governmental universities and three banks in Alexandria Governance. Another limitation is the use of a questionnaire instead of an experimental design, due to the low incentives for participants to take part in an experimental design, especially in Egypt. Future research, therefore, could be useful to increase the scope of this study by examining the different insights from the perspective of other stakeholder groups, such as reporters, professional accountants, financial analysts, portfolio managers, auditors, tax practitioners, IT experts, regulators, etc., and representing the whole country. In addition, future research should consider experiments of users' choice (e.g. financial analysts, institutional investors, and auditors) for multiple tasks where financial items are presented using both traditional and XBRL formats. As this study only explores the perception and understanding of XBRL in Egypt, it would be fruitful to address this matter in the Middle East and North Africa (MENA) region. Such cross-country study comparing the adoption rates and levels of stakeholders' perceptions and understandings of XBRL would be revealing for comparative aims, and to discover transferable experiences learnt (Dunne et al., 2013).

\section{Acknowledgements}

The authors thank Professor Aida Sy (the journal's Editor) and her anonymous reviewers for their insightful remarks and suggestions. The authors also acknowledge the financial support of Damanhour University, Egypt. 


\section{References}

Ahmed, A., Burton, B. and Dunne, T. (2017), "The determinants of corporate internet reporting in Egypt: an exploratory analysis", Journal of Accounting in Emerging Economies, Vol. 7 No. 1, pp. 35-60.

Alles, M. and Debreceny, R. (2012), “The evolution and future of XBRL research", International Journal of Accounting Information Systems, Vol. 13 No. 2, pp. 83-90.

Aly, D., Simon, J. and Hussainey, K. (2010), "Determinants of corporate Internet reporting: evidence from Egypt", Managerial Auditing Journal, Vol. 25 No. 2, pp. 182-202.

Apostolou, A. and Nanopoulos, K. (2009), "Interactive financial reporting using XBRL: an overview of the global markets and Europe", International Journal of Disclosure and Governance, Vol. 6 No. 3, pp. 262-272.

Avallone, F., Ramassa, P., \& Roncagliolo, E. (2016), “The pros and cons of XBRL adoption in Italy: a field study". Strengthening Information and Control Systems, pp. 157-170.

Baldwin, A.A. and Trinkle, B.S. (2011), "The impact of XBRL: a Delphi investigation", The International Journal of Digital Accounting Research, Vol. 11, pp. 1-24.

Beattie, V. and Pratt, K. (2003), "Issues concerning web-based business reporting: An analysis of the views of interested parties", British Accounting Review, Vol. 35 No. 2, pp. 155-187.

Birt, L., Muthusamy, K. and Bir, P. (2017), "XBRL and the Qualitative Characteristics of Useful Financial Information", Accounting Research Journal, Vol. 30 No. 1, pp. 107-126.

Bonson, E., Cortijo, V. and Escobar, T. (2009), "Towards the global adoption of XBRL using International Financial Reporting Standards (IFRS)", International Journal of Accounting Information Systems, Vol. 10 No. 1, pp. 46-60.

Boritz, J.E. and No, W.G. (2009), "Assurance on XBRL related documents: the case of United Technologies Corporation”, Journal of Information Systems, Vol. 23 No. 2, pp. 49-78.

Bovee, M., Ettredge, M.L., Srivastava, R.P. and Vasarhelyi, M.A. (2002), "Does the year 2000 XBRL taxonomy accommodate current business financial-reporting practice?", Journal of Information Systems, Vol. 16 No. 2, pp. 165-182.

Certified Financial Accountant (CFA) (2016),“CFA Institute Member Survey : XBRL ( Extensible Business Reporting Language )", No. November, pp. 1-24, available at: https://www.cfainstitute.org/Survey/survey_extensible_business_reporting_language_xbrl.p $\mathrm{df}$

Chen, S., Harris, L., Li, Wenying. and Wu, D. (2015), "How Does XBRL Affect the Cost of Equity Capital? Evidence from an Emerging Market", Journal of International Accounting Research, Vol. 14 No. 2, pp. 123-145.

Cohen, E.E., Schiavina, T. and Servais, O. (2005), "XBRL: the standardised business language for 21 st century reporting and governance", International Journal of Disclosure and Governance, Vol. 2 No. 4, pp. 368-394.

Debreceny, R. and Farewell, S. (2010), “XBRL in the accounting curriculum”, Issues in Accounting Education, Vol. 25 No. 3, pp. 379-403.

Debreceny, R., Farewell, S., Piechocki, M., Felden, C. and Gräning, A. (2010), “Does it add up? 
Early evidence on the data quality of XBRL filings to the SEC", Journal of Accounting and Public Policy, Vol. 29 No. 3, pp. 296-306.

Debreceny, R.S., Farewell, S.M., Piechocki, M., Felden, C., Gräning, A. and D’Eri, A. (2011), "Flex or break? Extensions in XBRL disclosures to the SEC", Accounting Horizons, Vol. 25 No. 4, pp. 631-657.

Dunne, T., Helliar, C., Lymer, A. and Mousa, R. (2013), "Stakeholder engagement in internet financial reporting: the diffusion of XBRL in the UK", British Accounting Review, Vol. 45 No. 3, pp. 167-182.

Egyptian Financial Supervisory Authority (EFSA) (2014), EGX Listing Rules. [accessed 20 May 2017, at http://www.egx.com.eg/English/listing_rules.aspx].

Egyptian Exchange (EGX) (2014), EGX Membership Rules. [accessed 21 May 2017, at http://www.egx.com.eg/english/Membership_rules.aspx].

Egyptian Accounting Standards (EAS) (2006), EAS 1: Presentation of Financial Statements. [accessed 3 October 2016, at https://www.efsa.gov.eg/content/efsa_ar/efsa2_merge_account/acount2.htm].

Egyptian Institute of Directors (EIoD) (2011), Code of Corporate Governance for Listed Companies. $\quad$ [accessed 14 December 2016, at http://www.ecgi.org/codes/documents/code_cg_egypt_13feb2011_ar.pdf].

Eierle, B., Ojala, H. and Penttinen, E. (2014), "XBRL to enhance external financial reporting: should we implement or not? Case Company X", Journal of Accounting Education, Vol. 32 No. 2, pp. 160-170.

Eni, L.C. (2015), "Empirical Research: Exploring Extensible Business Reporting Language and Views of Romanian Accountants", Procedia Economics and Finance, Vol. 32 No. 15, pp. 1675-1699.

Fedorowicz, J. (2011), "Integrating XBRL Into The Accounting Curriculum", The Review of Business Information Systems, Vol. 7 No. 4, pp. 51-62.

Field, A. (2013), Discovering statistics using IBM SPSS statistics, London: Sage.

Financial Accounting Standards Board (FASB) (1980), Quality Characteristics of Accounting Information. Statement of Financial Accounting Concepts No. 2. FASB, Stamford, CT.

Henderson, D., Sheetz, S.D. and Trinkle, B.S. (2012), "The determinants of inter-organizational and internal in-house adoption of XBRL: a structural equation model", International Journal of Accounting Information Systems, Vol. 13 No. 2, pp. 109-140.

Ilias, A., Razak, M., and Rahman, A. (2015), "The Expectation of Perceived Benefit of Extensible Business Reporting Language (XBRL): A Case in Malaysia", The Journal of Developing Areas, Vol. 49 No.5, pp. 263-271.

International Financial Reporting Standards (IFRS) (2013), "IFRS application around the world jurisdictional profile: Egypt."

Janvrin, D.J., Pinsker, R.E. and Mascha, M.F. (2013), "XBRL-enabled, spreadsheet, or PDF? Factors influencing exclusive user choice of reporting technology", Journal of Information Systems, Vol. 27 No. 2, pp. 35-49. 
Kim, J.W., Lim, J.-H. and No, W.G. (2012), "The effect of first wave mandatory XBRL reporting across the financial information environment", Journal of Information Systems, Vol. 26 No. 1 , pp. 127-153.

Nel, G.F. and Steenkamp, L.P. (2008), “An exploratory study of chartered accountants' awareness and understanding of XBRL”, Meditari Accountancy Research, Vol. 16 No. 1, pp. 79-93.

Papa, M. and Luisi, F. (2014), "Exploring the Usefulness of Extensible Business Reporting Language (XBRL) for Reporting Intellectual Capital (IC): Evidence From Italian Preparers", Journal of Modern Accounting and Auditing, Vol. 10 no. 5, pp. 537-550.

Pinsker, R. (2003), "XBRL awareness in auditing: a sleeping giant?", Managerial Auditing Journal, Vol. 18 No. 9, pp. 732-736.

Pinsker, R. and Li, S. (2008), "Costs and benefits of XBRL adoption", Communications of the ACM, Vol. 51 No. 3, pp. 47-50.

Pinsker, R. and Wheeler, P. (2009), "Nonprofessional investors' perceptions of the efficiency and effectiveness of XBRL-enabled financial statement analysis and of firms providing XBRLformatted information", International Journal of Disclosure and Governance, Vol. 6 No. 3, pp. 241-261.

Rawashdeh, A. and Selamat, M.H. (2013), "Critical success factors relating to the adoption of XBRL in Saudi Arabia", Journal of International Technology and Information Management, Vol. 22 No. 2, pp. 49-69.

Securities and Exchange Commission (2005), US Securities and Exchange Commission (SEC). Release Nos. 33-8529, 34-51129, 35-27944, IC-26747. XBRL Voluntary Financial Reporting Program on the EDGAR System. [accessed at http://www.sec.gov/answers/xbrl.htm].

Srivastava, R.P. and Kogan, A. (2010), "Assurance on XBRL instance document: a conceptual framework of assertions", International Journal of Accounting Information Systems, Vol. 11 No. 3, pp. 261-273.

Steenkamp, L.P. and Nel, G.F. (2012), "The adoption of XBRL in South Africa: an empirical study", The Electronic Library, Vol. 30 No. 3, pp. 409-425.

Troshani, I. and Lymer, A. (2010), "Translation in XBRL standardization", Information Technology \& People, Vol. 23 No. 2, pp. 136-164.

Valentinetti, D. and Rea, M.A. (2012), "IFRS taxonomy and financial reporting practices: the case of Italian listed companies", International Journal of Accounting Information Systems, Vol. 13 No. 2, pp. 163-180.

Vasarhelyi, M.A., Chan, D.Y. and Krahel, J.P. (2012), "Consequences of XBRL standardization on financial statement data”, Journal of Information Systems, Vol. 26 No. 1, pp. 155-167. 
Table 1. EGX-100 index of listed Egyptian companies and formats of financial reports

\begin{tabular}{|c|c|c|c|c|}
\hline No. & Industry name & No. of companies (\%) & Report format & No. of report format (\%) \\
\hline 1. & Real Estate & $21(21 \%)$ & $\begin{array}{c}\text { PDF } \\
\text { PHP } \\
\text { NA }\end{array}$ & $\begin{array}{c}17(17 \%) \\
2(2 \%) \\
2(2 \%)\end{array}$ \\
\hline 2. & Financial Services & $13(13 \%)$ & $\begin{array}{c}\text { PDF } \\
\text { HTML } \\
\text { PHP } \\
\text { NA }\end{array}$ & $\begin{array}{l}7(7 \%) \\
2(2 \%) \\
2(2 \%) \\
2(2 \%)\end{array}$ \\
\hline 3. & Food \& Beverage & $12(12 \%)$ & $\begin{array}{c}\text { PDF } \\
\text { HTML } \\
\text { NA }\end{array}$ & $\begin{array}{l}8(8 \%) \\
2(2 \%) \\
2(2 \%)\end{array}$ \\
\hline 4. & $\begin{array}{c}\text { Industrial Goods \& } \\
\text { Services \& Automobiles }\end{array}$ & $11(11 \%)$ & $\begin{array}{l}\text { PDF } \\
\text { NA }\end{array}$ & $\begin{array}{l}9(9 \%) \\
2(2 \%)\end{array}$ \\
\hline 5. & $\begin{array}{l}\text { Personal \& Household } \\
\text { Products }\end{array}$ & $8(8 \%)$ & $\begin{array}{c}\text { PDF } \\
\text { HTML }\end{array}$ & $\begin{array}{l}7(7 \%) \\
1(1 \%)\end{array}$ \\
\hline 6. & $\begin{array}{c}\text { Construction \& } \\
\text { Materials }\end{array}$ & $8(8 \%)$ & $\begin{array}{c}\text { PDF } \\
\text { NA } \\
\text { No website }\end{array}$ & $\begin{array}{l}5(5 \%) \\
1(1 \%) \\
2(2 \%)\end{array}$ \\
\hline 7. & Travel \& Leisure & $7(7 \%)$ & $\begin{array}{c}\text { PDF } \\
\text { HTML } \\
\text { NA } \\
\text { No website }\end{array}$ & $\begin{array}{l}3(3 \%) \\
1(1 \%) \\
2(2 \%) \\
1(1 \%)\end{array}$ \\
\hline 8. & Chemicals & $4(4 \%)$ & $\begin{array}{l}\text { PDF } \\
\text { PHP }\end{array}$ & $\begin{array}{l}3(3 \%) \\
1(1 \%)\end{array}$ \\
\hline 9. & Banks & $4(4 \%)$ & PDF & $4(4 \%)$ \\
\hline 10. & Basic Resources & $3(3 \%)$ & $\begin{array}{c}\text { PDF } \\
\text { NA }\end{array}$ & $\begin{array}{l}2(2 \%) \\
1(1 \%)\end{array}$ \\
\hline 11. & $\begin{array}{c}\text { Healthcare \& } \\
\text { Pharmaceuticals }\end{array}$ & $2(2 \%)$ & $\begin{array}{c}\text { NA } \\
\text { No website }\end{array}$ & $\begin{array}{l}1(1 \%) \\
1(1 \%)\end{array}$ \\
\hline 12. & Oil \& Gas & $2(2 \%)$ & $\begin{array}{c}\text { Excel/Word } \\
\text { NA }\end{array}$ & $\begin{array}{l}1(1 \%) \\
1(1 \%)\end{array}$ \\
\hline 13. & Telecommunications & $2(2 \%)$ & PDF & $2(2 \%)$ \\
\hline 14. & Technology & $1(1 \%)$ & PDF & $1(1 \%)$ \\
\hline 15. & Retail & $1(1 \%)$ & PDF & $1(1 \%)$ \\
\hline 16. & Media & $1(1 \%)$ & PDF & $1(1 \%)$ \\
\hline Total & 16 Industries & $100(100 \%)$ & $\begin{array}{c}\text { PDF } \\
\text { NA } \\
\text { HTML } \\
\text { PHP } \\
\text { No website } \\
\text { Excel/Word } \\
\text { XBRL }\end{array}$ & $\begin{array}{c}70(70 \%) \\
14(14 \%) \\
6(6 \%) \\
5(5 \%) \\
4(4 \%) \\
1(1 \%) \\
0(0 \%)\end{array}$ \\
\hline
\end{tabular}


Table 2. Respondents' demographic traits

\begin{tabular}{|c|c|c|c|}
\hline $\begin{array}{l}\text { Demographical } \\
\text { Information }\end{array}$ & Academics (\%) & Bankers (\%) & Total $(\%)$ \\
\hline \multicolumn{4}{|l|}{ - Age: } \\
\hline - 21-28 years & $32(56 \%)$ & $24(49 \%)$ & $56(53 \%)$ \\
\hline - 29-36 years & $16(28 \%)$ & $19(39 \%)$ & $35(33 \%)$ \\
\hline - 37-44 years & $7(12 \%)$ & $6(12 \%)$ & $13(12 \%)$ \\
\hline - 45-52 years & $2(4 \%)$ & $0(0 \%)$ & $2(2 \%)$ \\
\hline - 53-60 years & $0(0 \%)$ & $0(0 \%)$ & $\mathbf{0}(\mathbf{0 \%})$ \\
\hline - 60 and above & $0(0 \%)$ & $0(0 \%)$ & $0(0 \%)$ \\
\hline Total $(\%)$ & $57(100 \%)$ & $49(100 \%)$ & $106(100 \%)$ \\
\hline \multicolumn{4}{|l|}{ - Gender: } \\
\hline - Male & $37(65 \%)$ & $39(80 \%)$ & $76(72 \%)$ \\
\hline - Female & $20(35 \%)$ & $10(20 \%)$ & $30(28 \%)$ \\
\hline Total $(\%)$ & $57(100 \%)$ & $49(100 \%)$ & $106(100 \%)$ \\
\hline \multicolumn{4}{|l|}{$\begin{array}{l}\text { - Academic } \\
\text { Qualification: }\end{array}$} \\
\hline$-\mathrm{BSc}$ & $27(47 \%)$ & $27(55 \%)$ & $54(51 \%)$ \\
\hline - Diploma & $0(0 \%)$ & $20(41 \%)$ & $20(19 \%)$ \\
\hline - MSc & $22(39 \%)$ & $2(4 \%)$ & $24(22 \%)$ \\
\hline - PhD & $8(14 \%)$ & $0(0 \%)$ & $8(8 \%)$ \\
\hline Total (\%) & $57(100 \%)$ & $49(100 \%)$ & $106(100 \%)$ \\
\hline \multicolumn{4}{|l|}{ - Job Description: } \\
\hline & - Tutor: $\quad 27(47 \%)$ & - Accountant: $39(\mathbf{8 0} \%)$ & N/A \\
\hline & - Assistant lecturer: 22 (39\%) & - Loan manager: $9(\mathbf{1 8 \%})$ & N/A \\
\hline & - Lecturer: $\quad \mathbf{3}(\mathbf{5 \%})$ & - Sales manager: $\mathbf{1}(\mathbf{2 \%})$ & N/A \\
\hline & - Professor: & & N/A \\
\hline Total (\%) & $57(100 \%)$ & $49(100 \%)$ & N/A \\
\hline \multicolumn{4}{|l|}{ - Job Experience: } \\
\hline - Less than 5 years & $30(53 \%)$ & $23(47 \%)$ & $53(50 \%)$ \\
\hline$-5-10$ years & $19(33 \%)$ & $16(33 \%)$ & $35(33 \%)$ \\
\hline$-11-15$ years & $5(9 \%)$ & $7(14 \%)$ & $12(11 \%)$ \\
\hline - 16-20 years & $1(2 \%)$ & $3(6 \%)$ & $4(4 \%)$ \\
\hline - 21 and above & $2(3 \%)$ & $\mathbf{0}(\mathbf{0 \%})$ & $2(2 \%)$ \\
\hline Total $(\%)$ & $57(100 \%)$ & $49(100 \%)$ & $106(100 \%)$ \\
\hline
\end{tabular}


Table 3. Respondents' awareness of the financial reporting languages

\begin{tabular}{|c|c|c|c|c|c|c|c|c|c|c|c|c|c|c|}
\hline \multirow{3}{*}{ Reporting Language } & \multicolumn{5}{|c|}{ Academics $(n=57)$} & \multicolumn{5}{|c|}{ Bankers $(n=49)$} & \multicolumn{2}{|c|}{$\begin{array}{c}\text { Total } \\
\text { respondents } \\
(n=106)\end{array}$} & \multicolumn{2}{|c|}{$\begin{array}{c}\text { Kruskal-Wallis } \\
\text { test }\end{array}$} \\
\hline & \multicolumn{3}{|c|}{$\%$ of useable responses } & \multirow[b]{2}{*}{$\begin{array}{c}5- \\
\text { point } \\
\text { mean }\end{array}$} & \multirow[b]{2}{*}{$\begin{array}{l}\text { Std. } \\
\text { dev }\end{array}$} & \multicolumn{3}{|c|}{$\%$ of useable responses } & \multirow[b]{2}{*}{$\begin{array}{c}5- \\
\text { point } \\
\text { mean }\end{array}$} & \multirow[b]{2}{*}{$\begin{array}{l}\text { Std. } \\
\text { dev }\end{array}$} & \multirow[b]{2}{*}{$\begin{array}{c}5- \\
\text { point } \\
\text { mean }\end{array}$} & \multirow[b]{2}{*}{$\begin{array}{l}\text { Std. } \\
\text { dev }\end{array}$} & \multirow[b]{2}{*}{$\mathbf{X}^{2}$} & \multirow[b]{2}{*}{$\begin{array}{c}\text { Asymp. } \\
\text { sig }\end{array}$} \\
\hline & $\begin{array}{c}\text { A/TA } \\
4-5\end{array}$ & $\begin{array}{c}\text { SwA } \\
3\end{array}$ & $\begin{array}{c}\text { TNA/LA } \\
1-2\end{array}$ & & & $\begin{array}{c}\text { A/TA } \\
4-5\end{array}$ & $\begin{array}{c}\text { SwA } \\
3\end{array}$ & $\begin{array}{c}\text { TNA/LA } \\
1-2\end{array}$ & & & & & & \\
\hline Q1. Excel spreadsheet & $65 \%$ & $23 \%$ & $12 \%$ & 3.80 & 1.03 & $69 \%$ & $19 \%$ & $12 \%$ & 3.96 & 1.10 & 3.87 & 1.06 & 1.02 & 0.31 \\
\hline Q2. PDF files & $60 \%$ & $26 \%$ & $14 \%$ & 3.68 & 1.14 & $76 \%$ & $16 \%$ & $8 \%$ & 4.10 & 1.07 & 3.87 & 1.12 & 3.94 & 0.10 \\
\hline Q3. HTML web pages & $53 \%$ & $19 \%$ & $28 \%$ & 3.44 & 1.28 & $\mathbf{5 8 \%}$ & $20 \%$ & $12 \%$ & 3.80 & 1.08 & 3.60 & 1.20 & 1.91 & 0.18 \\
\hline Q4. XBRL & $11 \%$ & $18 \%$ & $71 \%$ & 2.04 & 1.13 & $6 \%$ & $24 \%$ & $70 \%$ & 2.10 & 0.95 & 2.06 & 1.05 & 0.41 & 0.52 \\
\hline
\end{tabular}

5-point Likert scale:

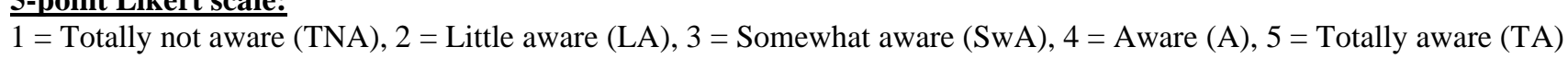


Table 4. Group 1 - Traditional balance sheets for A, B \& C banks

\begin{tabular}{|c|c|c|c|}
\hline Group 1: Traditional balance sheet & Academics (\%) & Bankers (\%) & Total (\%) \\
\hline \multicolumn{4}{|c|}{$\begin{array}{l}\text { Q5. Which bank from the above banks has the highest } \\
\text { balance in "Cash and due from Central Bank of Egypt" in } \\
2010\end{array}$} \\
\hline - Bank A & $44(78 \%)$ & $34(70 \%)$ & $78(74 \%)$ \\
\hline - Bank B & $3(5 \%)$ & $10(20 \%)$ & $13(12 \%)$ \\
\hline - Bank C & $7(12 \%)$ & $3(6 \%)$ & $10(9 \%)$ \\
\hline - Not exist & $3(5 \%)$ & $2(4 \%)$ & $5(5 \%)$ \\
\hline Total $(\%)$ & $57(100 \%)$ & $49(100 \%)$ & $106(100 \%)$ \\
\hline \multicolumn{4}{|l|}{ Q6. I thought that the task was very easy } \\
\hline - Strongly agree/agree & $33(57 \%)$ & $23(47 \%)$ & $56(53 \%)$ \\
\hline - Neither agree nor disagree & $10(18 \%)$ & $10(20 \%)$ & $20(19 \%)$ \\
\hline - Disagree/strongly disagree & $14(25 \%)$ & $16(33 \%)$ & $30(28 \%)$ \\
\hline Total (\%) & $57(100 \%)$ & $49(100 \%)$ & $106(100 \%)$ \\
\hline \multicolumn{4}{|c|}{$\begin{array}{l}\text { Q7. Which bank from the above banks' balance of } \\
\$ 25,155,762.4 \text { in "Available for Sale Investment" account } \\
\text { in } 2010 \text { ? Knowing that the exchange rate is } 1 \$=5.8 \mathrm{LE}\end{array}$} \\
\hline - Bank A & $6(11 \%)$ & $1(2 \%)$ & $7(7 \%)$ \\
\hline - Bank B & $14(24 \%)$ & $10(20 \%)$ & $24(22 \%)$ \\
\hline - Bank C & $6(11 \%)$ & $8(16 \%)$ & $14(13 \%)$ \\
\hline - Not exist & $31(54 \%)$ & $30(62 \%)$ & $61(58 \%)$ \\
\hline Total $(\%)$ & $57(100 \%)$ & $49(100 \%)$ & $106(100 \%)$ \\
\hline \multicolumn{4}{|l|}{ Q8. I thought that the task was very easy } \\
\hline - Strongly agree/agree & $20(35 \%)$ & $19(39 \%)$ & $39(37 \%)$ \\
\hline - Neither agree nor disagree & $12(21 \%)$ & $14(29 \%)$ & $26(25 \%)$ \\
\hline - Disagree/strongly disagree & $25(44 \%)$ & $16(33 \%)$ & $41(38 \%)$ \\
\hline Total $(\%)$ & $57(100 \%)$ & $49(100 \%)$ & $106(100 \%)$ \\
\hline \multicolumn{4}{|c|}{$\begin{array}{l}\text { Q9. Which bank from the above banks has the highest } \\
\text { balance in "Debt Ratio" in } 2010 \text { ? Knowing that debt ratio } \\
\text { = total liabilities/total assets }\end{array}$} \\
\hline - Bank A & $7(12 \%)$ & $3(6 \%)$ & $10(9 \%)$ \\
\hline - Bank B & $8(14 \%)$ & $8(15 \%)$ & $16(15 \%)$ \\
\hline - Bank C & $38(67 \%)$ & $34(69 \%)$ & $72(68 \%)$ \\
\hline - Not exist & $4(7 \%)$ & $4(8 \%)$ & $8(8 \%)$ \\
\hline Total $(\%)$ & $57(100 \%)$ & $49(100 \%)$ & $106(100 \%)$ \\
\hline \multicolumn{4}{|l|}{ Q10. I thought that the task was very easy } \\
\hline - Strongly agree/agree & $21(37 \%)$ & $8(16 \%)$ & $29(27 \%)$ \\
\hline - Neither agree nor disagree & $12(21 \%)$ & $18(37 \%)$ & $30(28 \%)$ \\
\hline - Disagree/strongly disagree & $24(42 \%)$ & $23(47 \%)$ & $47(45 \%)$ \\
\hline Total $(\%)$ & $57(100 \%)$ & $49(100 \%)$ & $106(100 \%)$ \\
\hline
\end{tabular}


Table 5. Group 2 - Balance sheets for D, E \& F banks in XBRL format

\begin{tabular}{|c|c|c|c|}
\hline Group 2: Balance sheet in XBRL format & Academics (\%) & Bankers (\%) & Total $(\%)$ \\
\hline \multicolumn{4}{|c|}{$\begin{array}{l}\text { Q11. Which bank from the above banks has the highest } \\
\text { balance in "Cash and due from Central Bank of Egypt" in } \\
2010\end{array}$} \\
\hline - Bank D & $4(7 \%)$ & $5(10 \%)$ & $9(8 \%)$ \\
\hline - Bank E & $1(2 \%)$ & $11(22 \%)$ & $12(11 \%)$ \\
\hline - Bank F & $50(87 \%)$ & $32(66 \%)$ & $82(78 \%)$ \\
\hline - Not exist & $2(4 \%)$ & $1(2 \%)$ & $3(3 \%)$ \\
\hline Total $(\%)$ & $57(100 \%)$ & $49(100 \%)$ & $106(100 \%)$ \\
\hline \multicolumn{4}{|l|}{ Q12. I thought that the task was very easy } \\
\hline - Strongly agree/agree & $52(91 \%)$ & $43(88 \%)$ & $95(89 \%)$ \\
\hline - Neither agree nor disagree & $4(7 \%)$ & $3(6 \%)$ & $7(7 \%)$ \\
\hline - Disagree/strongly disagree & $1(2 \%)$ & $3(6 \%)$ & $4(4 \%)$ \\
\hline Total $(\%)$ & $57(100 \%)$ & $49(100 \%)$ & $106(100 \%)$ \\
\hline \multicolumn{4}{|c|}{$\begin{array}{l}\text { Q13. Which bank from the above banks' balance of } \\
\$ 15,713,719,057 \text { in "Available for Sale Investment" account in } \\
2010 \text { ? Knowing that the exchange rate is } 1 \$=5.8 \mathrm{LE}\end{array}$} \\
\hline - Bank D & $4(7 \%)$ & $1(2 \%)$ & $5(5 \%)$ \\
\hline - Bank E & $1(2 \%)$ & $3(6 \%)$ & $4(4 \%)$ \\
\hline - Bank F & $43(75 \%)$ & $41(84 \%)$ & $84(79 \%)$ \\
\hline - Not exist & $9(16 \%)$ & $4(8 \%)$ & $13(12 \%)$ \\
\hline Total $(\%)$ & $57(100 \%)$ & $49(100 \%)$ & $106(100 \%)$ \\
\hline \multicolumn{4}{|l|}{ Q14. I thought that the task was very easy } \\
\hline - Strongly Agree/Agree & $50(88 \%)$ & $45(92 \%)$ & $95(90 \%)$ \\
\hline - Neither Agree nor Disagree & $6(10 \%)$ & $2(4 \%)$ & $8(7 \%)$ \\
\hline - Disagree/Strongly Disagree & $1(2 \%)$ & $2(4 \%)$ & $3(3 \%)$ \\
\hline Total $(\%)$ & $57(100 \%)$ & $49(100 \%)$ & $106(100 \%)$ \\
\hline \multicolumn{4}{|c|}{$\begin{array}{l}\text { Q15. Which bank from the above banks has the highest } \\
\text { balance in "Debt Ratio" in } 2010 \text { ? Knowing that the showing } \\
\text { diagram for debt ratio produced by XBRL program }\end{array}$} \\
\hline - Bank D & $2(4 \%)$ & $1(2 \%)$ & $3(3 \%)$ \\
\hline - Bank E & $2(4 \%)$ & $1(2 \%)$ & $3(3 \%)$ \\
\hline - Bank F & $53(92 \%)$ & $44(90 \%)$ & $97(91 \%$ \\
\hline - Not exist & $\mathbf{0}(\mathbf{0 \%})$ & $3(6 \%)$ & $3(3 \%$ \\
\hline Total $(\%)$ & $57(100 \%)$ & $49(100 \%)$ & $106(100 \%)$ \\
\hline \multicolumn{4}{|l|}{ Q16. I thought that the task was very easy } \\
\hline - Strongly agree/agree & $53(93 \%)$ & $44(90 \%)$ & $97(92 \%)$ \\
\hline - Neither agree nor disagree & $1(2 \%)$ & $2(4 \%)$ & $3(3 \%)$ \\
\hline - Disagree/strongly disagree & $3(5 \%)$ & $3(6 \%)$ & $6(5 \%)$ \\
\hline Total $(\%)$ & $57(100 \%)$ & $49(100 \%)$ & $106(100 \%)$ \\
\hline
\end{tabular}


Table 6. Respondents' views of the pros of using XBRL

\begin{tabular}{|c|c|c|c|c|c|c|c|c|c|c|c|c|c|c|}
\hline \multirow{3}{*}{ Pros of using XBRL } & \multicolumn{5}{|c|}{ Academics $(n=57)$} & \multicolumn{5}{|c|}{ Bankers $(n=49)$} & \multicolumn{2}{|c|}{$\begin{array}{l}\text { Total respondents } \\
\qquad(\mathrm{n}=106)\end{array}$} & \multicolumn{2}{|c|}{$\begin{array}{c}\text { Kruskal-Wallis } \\
\text { test }\end{array}$} \\
\hline & \multicolumn{3}{|c|}{ \% of useable responses } & \multirow{2}{*}{$\begin{array}{c}5- \\
\text { point } \\
\text { mean }\end{array}$} & \multirow{2}{*}{$\begin{array}{l}\text { Std. } \\
\text { dev }\end{array}$} & \multicolumn{3}{|c|}{$\begin{array}{c}\text { \% of useable } \\
\text { responses }\end{array}$} & \multirow{2}{*}{$\begin{array}{c}5- \\
\text { point } \\
\text { mean }\end{array}$} & \multirow{2}{*}{$\begin{array}{l}\text { Std. } \\
\text { dev }\end{array}$} & \multirow{2}{*}{$\begin{array}{c}\text { 5- } \\
\text { point } \\
\text { mean }\end{array}$} & \multirow{2}{*}{$\begin{array}{l}\text { Std. } \\
\text { dev }\end{array}$} & \multirow[b]{2}{*}{$\mathbf{X}^{2}$} & \multirow{2}{*}{$\begin{array}{l}\text { Asymp. } \\
\text { sig }\end{array}$} \\
\hline & $\begin{array}{c}\text { A/SA } \\
4-5\end{array}$ & $\begin{array}{l}\mathbf{N} \\
\mathbf{3}\end{array}$ & $\begin{array}{l}\text { SD/D } \\
1-2\end{array}$ & & & $\begin{array}{c}\text { A/SA } \\
4-5\end{array}$ & $\begin{array}{l}\mathbf{N} \\
\mathbf{3}\end{array}$ & $\begin{array}{c}\text { SD/D } \\
1-2\end{array}$ & & & & & & \\
\hline $\begin{array}{l}\text { Q17. XBRL can contribute to speeding up the } \\
\text { reporting cycle to take decision in the right time }\end{array}$ & $\mathbf{9 4 \%}$ & $4 \%$ & $2 \%$ & 4.65 & 0.64 & $94 \%$ & $2 \%$ & $4 \%$ & 4.55 & 0.82 & 4.60 & 0.73 & 0.27 & 0.60 \\
\hline $\begin{array}{l}\text { Q18. XBRL can help reduce re-entering financial } \\
\text { data errors }\end{array}$ & $93 \%$ & $5 \%$ & $2 \%$ & 4.53 & 0.76 & $84 \%$ & $14 \%$ & $2 \%$ & 4.31 & 0.87 & 4.42 & 0.82 & 2.14 & 0.14 \\
\hline $\begin{array}{l}\text { Q19. XBRL make the financial report available in the } \\
\text { right time for taking decisions }\end{array}$ & $87 \%$ & $9 \%$ & $4 \%$ & 4.50 & 0.87 & $92 \%$ & $4 \%$ & $4 \%$ & 4.40 & 0.84 & 4.45 & 0.85 & 1.21 & 0.30 \\
\hline $\begin{array}{l}\text { Q20. XBRL can provide interoperability with other } \\
\text { existing applications/systems which save time and } \\
\text { effort }\end{array}$ & $87 \%$ & $9 \%$ & $4 \%$ & 4.44 & 0.87 & $90 \%$ & $4 \%$ & $6 \%$ & 4.31 & 0.90 & 4.38 & 0.88 & 1.10 & 0.30 \\
\hline $\begin{array}{l}\text { Q21. XBRL can reduce the effort of re-keying } \\
\text { financial data }\end{array}$ & $81 \%$ & $14 \%$ & $5 \%$ & 4.25 & 0.90 & $94 \%$ & $4 \%$ & $2 \%$ & 4.50 & 0.68 & 4.36 & 0.81 & 1.65 & 0.20 \\
\hline $\begin{array}{l}\text { Q22. XBRL can reduce the cost of generating and } \\
\text { analysing financial reports by making reports } \\
\text { comparable }\end{array}$ & $84 \%$ & $12 \%$ & $4 \%$ & 4.28 & 0.82 & $84 \%$ & $12 \%$ & $4 \%$ & 4.24 & 0.83 & 4.26 & 0.82 & 0.60 & 0.82 \\
\hline Q23. XBRL fosters data comparability & $89 \%$ & $9 \%$ & $2 \%$ & 4.50 & 0.74 & $86 \%$ & $10 \%$ & $4 \%$ & 4.40 & 0.84 & 4.45 & 0.78 & 0.30 & 0.60 \\
\hline $\begin{array}{l}\text { Q24. XBRL can solve the problem of different } \\
\text { languages of financial reports }\end{array}$ & $84 \%$ & $14 \%$ & $2 \%$ & 4.44 & 0.87 & $90 \%$ & $8 \%$ & $2 \%$ & 4.41 & 0.73 & 4.42 & 0.80 & 0.43 & 0.51 \\
\hline $\begin{array}{l}\text { Q25. XBRL can solve the problem of different } \\
\text { currencies for different financial reports }\end{array}$ & $80 \%$ & $16 \%$ & $4 \%$ & 4.33 & 0.93 & $\mathbf{8 8 \%}$ & $8 \%$ & $4 \%$ & 4.33 & 0.80 & 4.33 & 0.87 & 0.20 & 0.66 \\
\hline $\begin{array}{l}\text { Q26. XBRL and IFRS allow for easier harmonization } \\
\text { for financial reporting on the international level }\end{array}$ & $81 \%$ & $17 \%$ & $2 \%$ & 4.23 & 0.87 & $78 \%$ & $16 \%$ & $6 \%$ & 4.10 & 0.96 & 4.17 & 0.91 & 0.36 & 0.55 \\
\hline $\begin{array}{l}\text { Q27. XBRL can improve the analysis of financial } \\
\text { information }\end{array}$ & $91 \%$ & $7 \%$ & $2 \%$ & 4.47 & 0.71 & $80 \%$ & $18 \%$ & $2 \%$ & 4.35 & 0.86 & 4.42 & 0.78 & 0.30 & 0.60 \\
\hline Q28. XBRL can reduce time required to analyse data & $91 \%$ & $7 \%$ & $2 \%$ & 4.53 & 0.78 & $\mathbf{9 0 \%}$ & $6 \%$ & $4 \%$ & 4.37 & 0.78 & 4.45 & 0.78 & 1.80 & 0.18 \\
\hline $\begin{array}{l}\text { Q29. XBRL can speed up the process of finding } \\
\text { information in the financial reports using XBRL } \\
\text { search engine }\end{array}$ & $82 \%$ & $14 \%$ & $4 \%$ & 4.40 & 0.92 & $90 \%$ & $6 \%$ & $4 \%$ & 4.35 & 0.78 & 4.38 & 0.86 & 0.85 & 0.36 \\
\hline
\end{tabular}

5-point Likert scale:

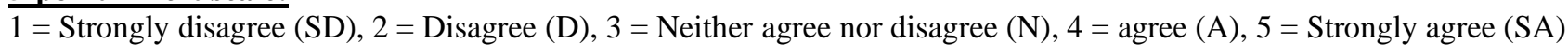


Table 7. Respondents' views of the cons of using XBRL

\begin{tabular}{|c|c|c|c|c|c|c|c|c|c|c|c|c|c|c|}
\hline \multirow{3}{*}{ Cons of using XBRL } & \multicolumn{5}{|c|}{ Academics $(n=57)$} & \multicolumn{5}{|c|}{ Bankers $(n=49)$} & \multicolumn{2}{|c|}{$\begin{array}{l}\text { Total respondents } \\
\qquad(\mathbf{n}=\mathbf{1 0 6})\end{array}$} & \multicolumn{2}{|c|}{$\begin{array}{c}\text { Kruskal-Wallis } \\
\text { test }\end{array}$} \\
\hline & \multicolumn{3}{|c|}{$\%$ of useable responses } & \multirow{2}{*}{$\begin{array}{c}5- \\
\text { point } \\
\text { mean }\end{array}$} & \multirow[b]{2}{*}{$\begin{array}{l}\text { Std. } \\
\text { dev }\end{array}$} & \multicolumn{3}{|c|}{$\begin{array}{c}\text { \% of useable } \\
\text { responses }\end{array}$} & \multirow{2}{*}{$\begin{array}{c}5- \\
\text { point } \\
\text { mean }\end{array}$} & \multirow[b]{2}{*}{$\begin{array}{l}\text { Std. } \\
\text { dev }\end{array}$} & \multirow{2}{*}{$\begin{array}{c}\text { 5- } \\
\text { point } \\
\text { mean }\end{array}$} & \multirow[b]{2}{*}{$\begin{array}{l}\text { Std. } \\
\text { dev }\end{array}$} & \multirow[b]{2}{*}{$\mathbf{X}^{2}$} & \multirow[b]{2}{*}{$\begin{array}{l}\text { Asymp. } \\
\text { sig }\end{array}$} \\
\hline & $\begin{array}{c}\text { A/SA } \\
\mathbf{4 - 5}\end{array}$ & $\begin{array}{l}\mathbf{N} \\
\mathbf{3}\end{array}$ & $\begin{array}{c}\text { SD/D } \\
1-2\end{array}$ & & & $\begin{array}{c}\text { A/SA } \\
4-5\end{array}$ & $\begin{array}{l}\mathbf{N} \\
\mathbf{3}\end{array}$ & $\begin{array}{c}\text { SD/D } \\
1-2\end{array}$ & & & & & & \\
\hline Q30. Cost of XBRL software & $53 \%$ & $40 \%$ & $7 \%$ & 3.61 & 1.01 & $57 \%$ & $39 \%$ & $4 \%$ & 3.88 & 1.01 & 3.74 & 1.02 & 1.47 & 0.23 \\
\hline Q31. Time needed to learn about XBRL & $42 \%$ & $44 \%$ & $14 \%$ & 3.40 & 0.98 & $43 \%$ & $45 \%$ & $12 \%$ & 3.53 & 0.98 & 3.45 & 0.98 & 0.27 & 0.60 \\
\hline Q32. Effort needed to learn about XBRL & $42 \%$ & $46 \%$ & $12 \%$ & 3.44 & 0.90 & $47 \%$ & $47 \%$ & $6 \%$ & 3.61 & 0.86 & 3.52 & 0.89 & 0.86 & 0.35 \\
\hline $\begin{array}{l}\text { Q33. Lack of available software for displaying and } \\
\text { analysing XBRL instance documents }\end{array}$ & $51 \%$ & $39 \%$ & $10 \%$ & 3.53 & 0.91 & $51 \%$ & $45 \%$ & $4 \%$ & 3.60 & 0.76 & 3.56 & 0.84 & 0.05 & 0.82 \\
\hline $\begin{array}{l}\text { Q34. Difficulty to create XBRL Egyptian official } \\
\text { taxonomy }\end{array}$ & $49 \%$ & $42 \%$ & $9 \%$ & 3.67 & 1.02 & $55 \%$ & $41 \%$ & $4 \%$ & 3.67 & 0.88 & 3.67 & 0.95 & 0.02 & 0.90 \\
\hline $\begin{array}{l}\text { Q36. Different technical ways of implementing } \\
\text { XBRL due to different taxonomies }\end{array}$ & $51 \%$ & $45 \%$ & $4 \%$ & 3.63 & 0.86 & $61 \%$ & $29 \%$ & $10 \%$ & 3.84 & 1.10 & 3.73 & 0.96 & 1.63 & 0.20 \\
\hline $\begin{array}{l}\text { Q37. No specific approach for XBRL adoption } \\
\text { due to non-equivalence of success adoption cases } \\
\text { for different countries }\end{array}$ & $46 \%$ & $47 \%$ & $7 \%$ & 3.54 & 0.85 & $47 \%$ & $43 \%$ & $10 \%$ & 3.65 & 1.10 & 3.60 & 0.95 & 0.31 & 0.58 \\
\hline $\begin{array}{l}\text { Q38. Difficulty to implement new procedures to } \\
\text { analyse XBRL documents }\end{array}$ & $49 \%$ & $39 \%$ & $12 \%$ & 3.47 & 0.91 & $47 \%$ & $37 \%$ & $16 \%$ & 3.61 & 1.10 & 3.54 & 1.00 & 0.27 & 0.61 \\
\hline $\begin{array}{l}\text { Q39. Difficulty to create extension taxonomy for } \\
\text { each company. }\end{array}$ & $37 \%$ & $56 \%$ & $7 \%$ & 3.42 & 0.86 & $39 \%$ & $43 \%$ & $18 \%$ & 3.41 & 1.02 & 3.42 & 0.94 & 0.10 & 0.78 \\
\hline Q40. Fear of change to XBRL & $53 \%$ & $35 \%$ & $12 \%$ & 3.51 & 0.97 & $\mathbf{5 7 \%}$ & $31 \%$ & $12 \%$ & 3.61 & 1.10 & 3.56 & 1.02 & 0.48 & 0.50 \\
\hline $\begin{array}{l}\text { Q41. Lack of training courses for developing } \\
\text { required skills to apply XBRL for accountants }\end{array}$ & $65 \%$ & $26 \%$ & $9 \%$ & 3.84 & 1.10 & $62 \%$ & $18 \%$ & $20 \%$ & 3.55 & 1.16 & 3.71 & 1.13 & 1.68 & 0.20 \\
\hline $\begin{array}{l}\text { Q42. Non-existence of Egyptian taxonomy } \\
\text { consistent with the Egyptian standards. }\end{array}$ & $63 \%$ & $30 \%$ & $7 \%$ & 3.84 & 1.03 & $61 \%$ & $31 \%$ & $8 \%$ & 3.80 & 1.00 & 3.82 & 1.01 & 0.10 & 0.75 \\
\hline $\begin{array}{l}\text { Q43. High cost of training individuals to work } \\
\text { with XBRL }\end{array}$ & $54 \%$ & $39 \%$ & $7 \%$ & 3.72 & 1.03 & $53 \%$ & $35 \%$ & $12 \%$ & 3.76 & 1.10 & 3.74 & 1.05 & 0.01 & 0.94 \\
\hline
\end{tabular}

\section{5-point Likert scale:}

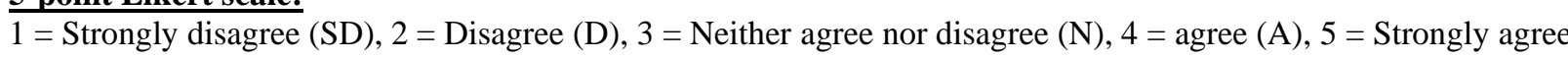




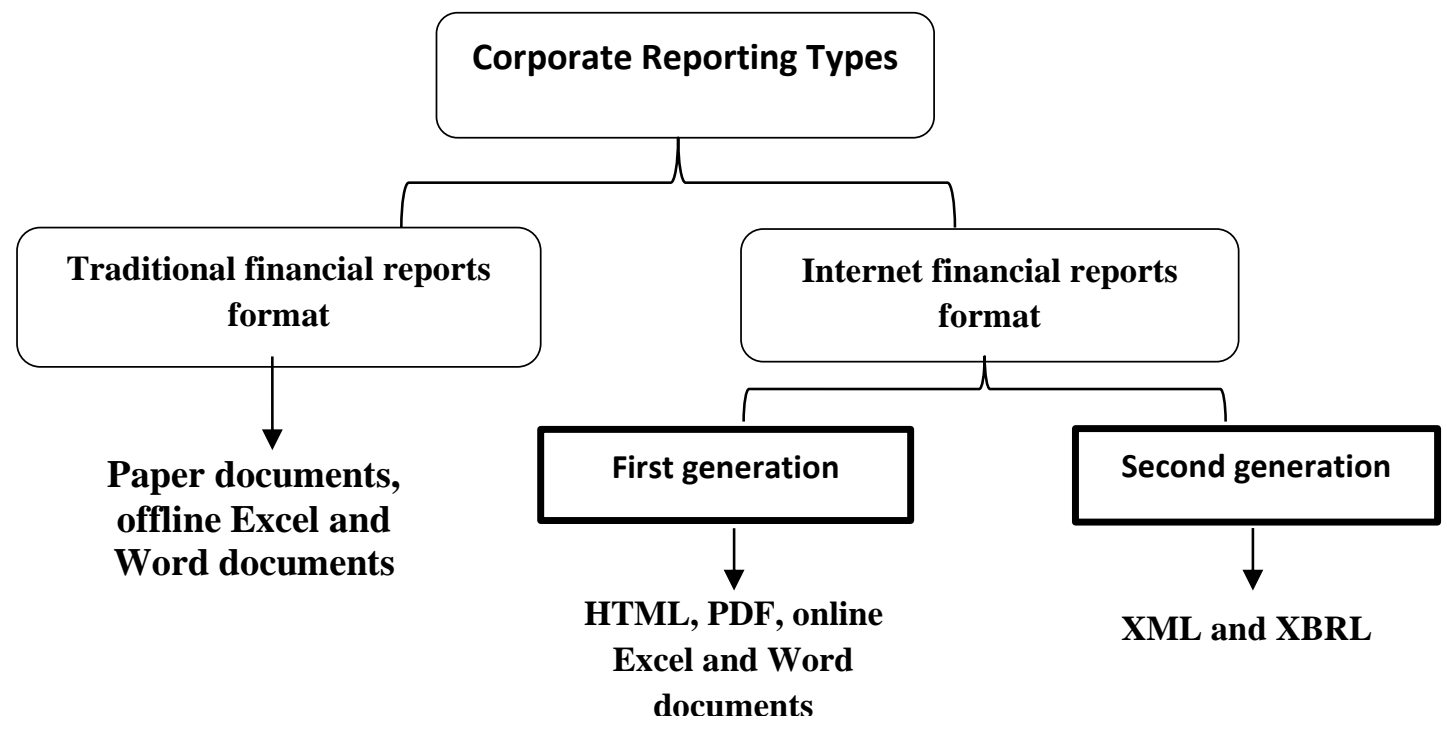

Fig. 1. Corporate reporting types

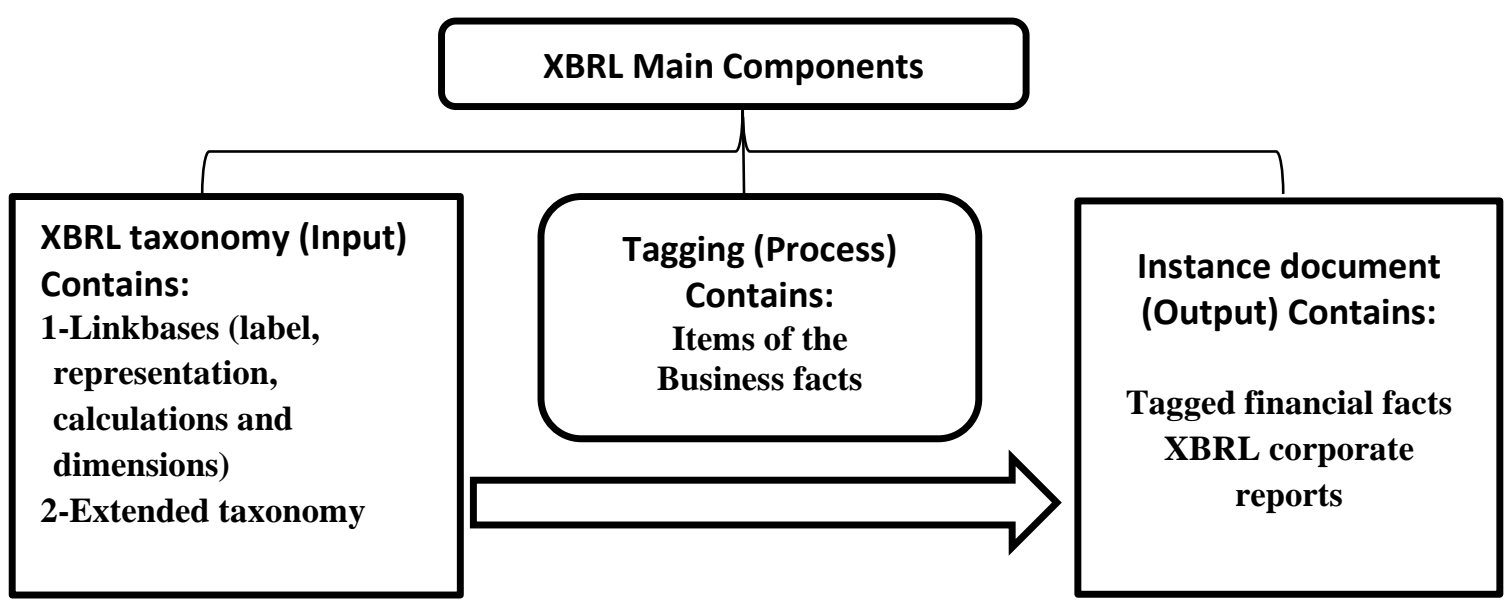

Fig. 2. XBRL main components 